RESEARCH ARTICLE

\title{
Assessment of the contents of a selected macro, micro and toxic elements in ripen bael fruits and tender shoots of water spinach and sweet potato using XRF and ICP-MS methods
}

\author{
C.K. Pathirana ${ }^{1,2, *}$, L.T. Ranaweera ${ }^{3}$, S.A.T. Lakshan ${ }^{4}$, T. Madhujith ${ }^{2,4}$ and J.P. Eeswara ${ }^{1,2}$ \\ ${ }^{1}$ Department of Crop Science, Faculty of Agriculture, University of Peradeniya, Peradeniya, Sri Lanka \\ ${ }^{2}$ Postgraduate Institute of Agriculture, University of Peradeniya, Peradeniya, Sri Lanka \\ ${ }^{3}$ Department of Molecular Biology and Biotechnology, Faculty of Science, University of Peradeniya, Peradeniya, \\ Sri Lanka \\ ${ }^{4}$ Department of Food Science and Technology, Faculty of Agriculture, University of Peradeniya, Peradeniya, Sri Lanka
}

\begin{abstract}
Macro and micro elemental nutrient profiles and compositions of toxic heavy metals in food items are important attributes in culinary and nutrition sciences. We selected ripen bael fruits of elite accessions selected for large-scale cultivation in Sri Lanka, Kankong, a green leafy vegetable prone to bioaccumulation of toxic heavy metals (market and commercially available samples) and shoot-tops of sweet potato, an underutilized leafy vegetable to detect the elemental compositions using X-ray fluorescence (XRF) and Inductive Coupled Plasma Mass Spectrometric (ICP-MS) methods. Bael pulp was extracted from ripe fruits and, Kankong and sweet potato shoot-tops were collected. The presence and absence of elements were assessed using XRF. The elemental contents were measured using ICP-MS, and statistically analyzed. Bael and SP samples did not contain toxic heavy metals $\mathrm{As}$ and $\mathrm{Pb}$ whereas Kankong samples collected from a municipal wastewater drain contained all these toxic elements in large quantities. Kankong samples purchased from open market contained $\mathrm{Hg}, \mathrm{Cd}$, As and $\mathrm{Cr}$. It is also noted that $\mathrm{Pb}$ separately correlated with $\mathrm{Cr}, \mathrm{Fe}, \mathrm{Co}$, $\mathrm{Zn}, \mathrm{Ni}$ and $\mathrm{Hg}$ contents in Kankong implying that they are under a common absorption mechanism or coming from a common source in the polluted habitat. The present study concludes that Kankong in Sri Lanka is unsafe for consumption and SP is an alternative to replace Kankong.
\end{abstract}

Keywords: Green leafy vegetable, Bael fruits, Kankong, Underutilized leafy vegetable, Heavy metals in food, sweet potato as a leafy vegetable.

\section{INTRODUCTION}

The macro and micronutrients present in the food are essential for a healthy life. The exact amounts of these elements present in the food items must be measured to understand the nutritional balance of the diets and to produce the value-added products in large-scale. Bael (Aegle marmelos L.) is a medicinal fruit species that has been subjected to many pharmacological and nutritional research studies. The elemental composition in bael has been studied in India using fruit pulp, bark, and leaf tissues (Kaur and Kalia, 2017; Mishra et al., 2012; Sing et al.,
2012). However, in Sri Lanka, no such studies have been conducted to date. The accurate estimation of the elemental (macro and micronutrients) profiles in bael are very important in producing herbal drugs using fruit pulp and popularize as a medicinally valuable fruit species across all classes of the society, because, currently bael is mainly popular in rural areas and among older adults.

In addition to the macro and micronutrients, sometimes toxic heavy metals are also present in food. The toxic heavy metals in food are often linked to many ailments in the modern context. The industrial activities release toxic heavy metals to the soil systems on daily basis. Depending on the specific genetic capabilities, plants bioaccumulate toxic heavy metals after absorbing them through the root systems. The toxic heavy metals get accumulated through food chains and also enter into human bodies through direct and indirect consumption. Cancers, kidney diseases and neurological disorders are frequently linked to the presence of toxic heavy metals in food and drinking water. Therefore, the assessment of the presence/absence and quantities of toxic heavy metals in food items is an important aspect in formulating food safety guidelines. Historically, bael is considered as a medicinally rich food source thus it can be used as a reference material to compare the contents of toxic heavy metals with the other plant-based food such as green leafy vegetables (GLV) which are more prone to bioaccumulation of toxic heavy metals than any other plantbased food items (Göthberg et al., 2002). Since modern agricultural and home garden soils are frequently getting contaminated with toxic heavy metals, bael can be used as a reference species to check the absorption of toxic heavy metals. Out of the array of diverse GLVs, Ipomea aquatica (Kankong or water spinach) is reported to be the most vulnerable species known to bioaccumulate toxic heavy metals (Liu et al., 2005; Marcussen et al., 2008). Kankong is a popular and nutritious leafy vegetable in many parts of the world (Karmakar et al., 2013). It is a frequent component in household and hotel based cousins in Sri Lanka. Many studies reported that Kankong is not safe to consume if 
the produce is coming from polluted habitats (Göthberg et al., 2002). Although, the problem of bioaccumulating toxic heavy metals in Kankong is considered as a serious health concern, sparse studies are published regarding the profiles of toxic heavy metals in Kankong available in the market or in the polluted sites of Sri Lanka. Since Kankong is not safe to eat if grown in polluted places and there is no way to decide that commercially available Kankong is contaminated, an alternative leafy vegetable to Kankong is very important. I. batatas [sweet potato (SP)] tender shoots are considered as a safe alternative to Kankong, because it can be prepared as dishes very similar to Kankong and has no tendency to accumulate toxic heavy metals as reported in many studies. SP leaves and tender shoots are reported to be very highly nutritious and nutritionally richer than I. aquatica (Menelaou et al., 2006; Mulokozi et al., 2007; Islam, 2014; Nagai et al., 2011). However, the exact elemental profiles in the edible shoot-tops of sweet potato grown in Sri Lanka have not been studied in detail. Therefore, it is essential to assess the toxic and other elemental profiles in Kankong and SP in comparison to a safe food item such as a medicinal plant like bael.

The elemental profiles of biological samples could be assessed using a variety of methods. The wet lab methods yield data for a single element, and the throughput of the data collection is low hindering the capability of assessing many elements at the same time. The Inductively Coupled Plasma Mass Spectrometry (ICP-MS) produces high throughput elemental data (Diyabalanage et al., 2017). However, the sample preparation for such techniques take time, and the required equipments are expensive. In comparison, X-ray fluorescence (XRF) is often used as a relatively easy analytical method to qualitatively assess the elemental contents. Thus, in the present study, we employed XRF to detect the presence and ICP-MS to confirm the presence and measure the contents of selected elements in shoot-tops of Kankong, SP in comparison to bael fruits under Sri Lankan context.

\section{MATERIALS AND METHODS}

\section{Plant material}

The fully ripen bael fruits were collected from five elite accessions, Beheth Beli (BB), Mawanella (MA), Paragammana (PA), Polonnaruwa-Supun (PS) and, Rambukkana (RA), identified by the Fruit Research and Development Center of the Department of Agriculture, Sri Lanka. The fruits were harvested during the peak fruiting season of 2017 and stored at $\quad-80{ }^{\circ} \mathrm{C}$ till processing for analysis. The pulp was removed from the bale fruits and subjected to oven drying at $80{ }^{\circ} \mathrm{C}$. After drying, solidified samples were generated, and they were crushed using mortars and pestles to obtain finely powdered samples (average particle size to be $50 \mu \mathrm{m}$ ). The immature shoottop samples were collected from Kankong and SP. The Kankong samples were collected from a wastewater drain in Kandy Municipal Council, Sri Lanka (herein after referred to as $\mathrm{KMu}$ ) and commercial vegetable market in the same area (herein after referred to as KMa). The SP samples were collected from a farming field in Kandy.
Soon after harvesting, the shoot-top samples of Kankong and SP were oven dried at $80{ }^{\circ} \mathrm{C}$ for three days to obtain constant dry weight. The dried samples were crushed to obtain a fine powder.

\section{XRF elemental analysis}

The powdered samples (10 replicates for each of five bael accessions, KMa and $\mathrm{KMu}$ ) were subjected to X-ray fluorescence (XRF) analysis using Fischerscope X-Ray Xan instrument (BW/526/00/Ro-Type: XAN). The powdered samples were mounted to a circular frame (2.5 $\mathrm{cm}$ diameter and $1.5 \mathrm{~cm}$ of height). A special parafilm was placed at the bottom of the circular frame, and the sample was filled up to $50 \%$ of the height. The X-ray beam was sent from the bottom for the analysis of elemental contents (Nielson et al., 1991). The standard samples were used to calibrate the XRF analysis. The frequency range of the XRF beam was calibrated using $\mathrm{S}, \mathrm{Ti}, \mathrm{Cr}, \mathrm{Ni}, \mathrm{Cu}, \mathrm{Zn}, \mathrm{Zr}$, Mo, Ag. Sn, W, Au, and Pb standard metal plate (CALSS Pure Elements Analysis). The generated spectra were converted to elemental contents in $\mathrm{mg} / \mathrm{kg}$ based on the dry weights (Wijewardana et al., 2016; Kavitha and Ramadas, 2013) for detailed data analysis.

\section{ICP-MS elemental analysis}

A mass of $0.2 \mathrm{~g}$ of each ground sample was mixed with $10 \mathrm{ml}$ of $1 \mathrm{M} \mathrm{HNO}_{3}$ and $1 \mathrm{ml}$ of $\mathrm{H}_{2} \mathrm{O}_{2}$. The sample was digested for 30 mins at $180{ }^{\circ} \mathrm{C}$ in a Microwave Digester. Then contents of the elements; $\mathrm{K}, \mathrm{Ca}, \mathrm{S}, \mathrm{Fe}, \mathrm{Mn}, \mathrm{Zn}, \mathrm{Cu}$, $\mathrm{Ni}, \mathrm{Co}, \mathrm{Hg}, \mathrm{Cd}, \mathrm{As}, \mathrm{Cr}, \mathrm{Sb}, \mathrm{Sn}$, and $\mathrm{Pb}$, of the experimental samples and the standards were measured using ICP-MS Thermo analyzer (Thermo-Fisher Scientific Inc., Bremen, Germany). The elemental contents were calculated using the following equation.

$$
\mathrm{M}(\mathrm{mg} / \mathrm{kg})=\left(\mathrm{Q}_{1}-\mathrm{Q}_{0}\right) k \mathrm{~V} / \mathrm{w}
$$

M: Mass of the element

$\mathrm{Q}_{1}$ : Concentration of the element in the sample to be tested $\mathrm{Q}_{0}$ : Concentration of the element in the control

\section{$k$ : Dilution factor}

\section{V: Final sample volume}

w: Weight of the ground sample used

\section{Data analysis}

The elemental contents given by XRF were used to assess the presence and absence of the elements. The elemental contents given by ICP-MS were subjected to ANOVA procedure in the statistical package SAS 9.4 (SAS Institute, NC, Cary, USA), and DUNCAN mean separation procedure. The elemental contents in all the samples were also subjected to multiple regression procedure to obtain a dendrogram using Euclidian Distance and Average Linkage algorithms in SAS. Since some of the elements were absent in bael and SP (see Table 1), Pearson's Correlation Coefficients (PCC) were calculated for pair-wise elemental contents separately for three species. 


\section{RESULTS}

\section{XRF based assessment of the elemental contents}

The presence and absence of the elements of tested samples are given in Table 1 and the representative XRF spectral graphs showing the peaks for different elements obtained
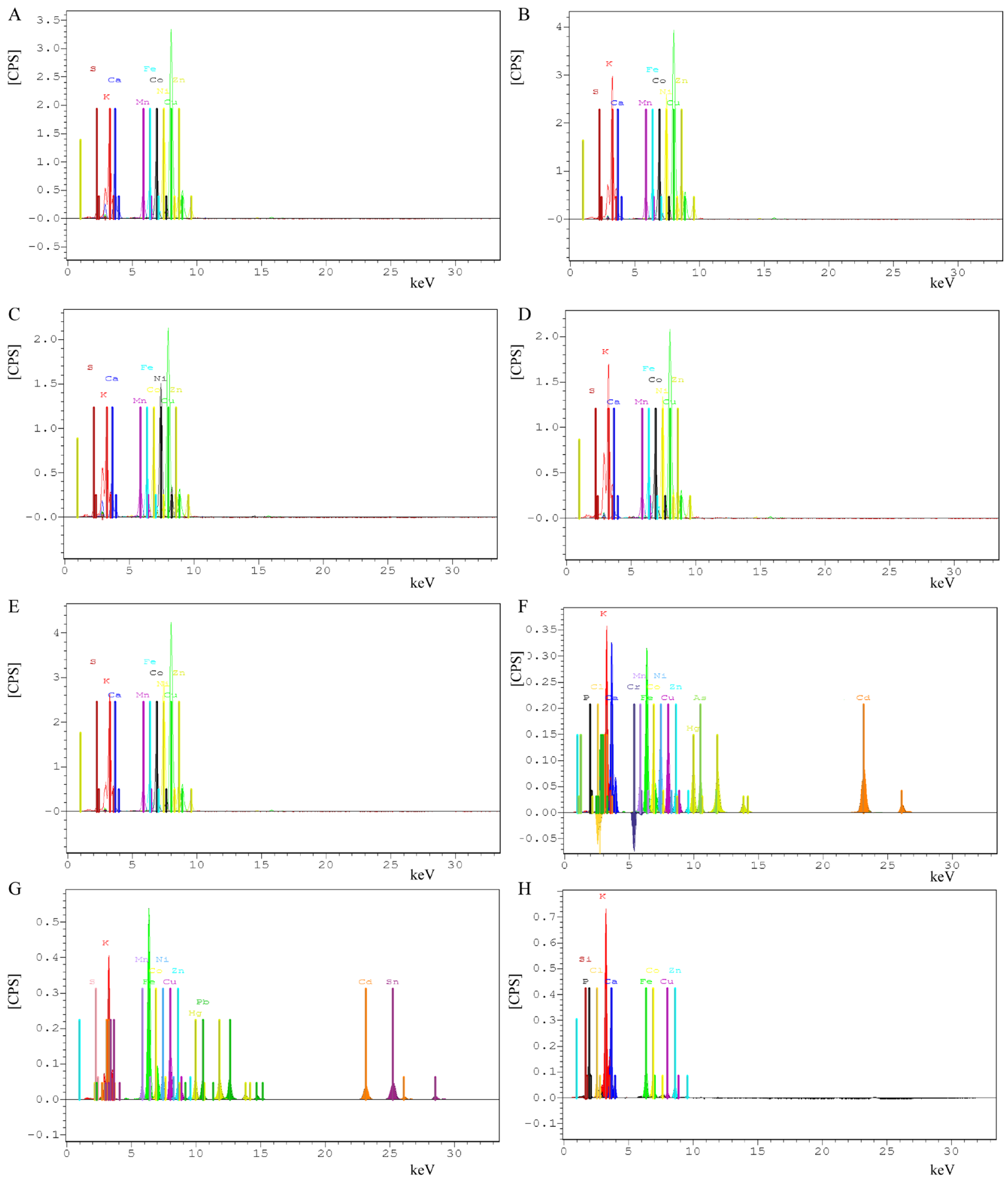

Figure 1: Representative graphical outputs of XRF analysis. The $\mathrm{x}$ and $\mathrm{y}$ axes stand for kilo electron Volts (KeV) and Counts Per Second (CPS) respectively. A: BB, B: MA, C: PA, D: PS, E: RA, F: KMa, G: KMu, H: SP. 
Table 1: The presence of elements in the shoot-tops of Kankong and sweet potato and, ripe bael fruits based on XRF.

\begin{tabular}{llllllllll}
\hline \multirow{2}{*}{$\begin{array}{l}\text { Element } \\
\text { (mg/kg) }\end{array}$} & \multicolumn{1}{l}{ Bael Accession } & $\boldsymbol{B} \boldsymbol{B}$ & MA & PA & PS & RA & Market & Municipal drain & Sweet potato \\
\hline $\mathrm{K}$ & $\checkmark$ & $\checkmark$ & $\checkmark$ & $\checkmark$ & $\checkmark$ & $\checkmark$ & $\checkmark$ & $\checkmark$ \\
$\mathrm{Ca}$ & $\checkmark$ & $\checkmark$ & $\checkmark$ & $\checkmark$ & $\checkmark$ & $\checkmark$ & $\checkmark$ & $\checkmark$ \\
$\mathrm{Fe}$ & $\checkmark$ & $\checkmark$ & $\checkmark$ & $\checkmark$ & $\checkmark$ & $\checkmark$ & $\checkmark$ & $\checkmark$ \\
$\mathrm{Mn}$ & $\checkmark$ & $\checkmark$ & $\checkmark$ & $\checkmark$ & $\checkmark$ & $\checkmark$ & $\checkmark$ & $\times$ \\
$\mathrm{Zn}$ & $\checkmark$ & $\checkmark$ & $\checkmark$ & $\checkmark$ & $\checkmark$ & $\checkmark$ & $\checkmark$ & $\checkmark$ \\
$\mathrm{Cu}$ & $\checkmark$ & $\checkmark$ & $\checkmark$ & $\checkmark$ & $\checkmark$ & $\checkmark$ & $\checkmark$ & $\checkmark$ \\
$\mathrm{Ni}$ & $\checkmark$ & $\checkmark$ & $\checkmark$ & $\checkmark$ & $\checkmark$ & $\checkmark$ & $\checkmark$ & $\checkmark$ \\
$\mathrm{Co}$ & $\checkmark$ & $\checkmark$ & $\checkmark$ & $\checkmark$ & $\checkmark$ & $\checkmark$ & $\checkmark$ & $\times$ \\
$\mathrm{Hg}$ & $\times$ & $\times$ & $\times$ & $\times$ & $\times$ & $\checkmark$ & $\checkmark$ & $\times$ \\
$\mathrm{Cd}$ & $\times$ & $\times$ & $\times$ & $\times$ & $\times$ & $\checkmark$ & $\checkmark$ & $\times$ \\
$\mathrm{As}$ & $\times$ & $\times$ & $\times$ & $\times$ & $\times$ & $\checkmark$ & $\checkmark$ & $\times$ \\
$\mathrm{Cr}$ & $\times$ & $\times$ & $\times$ & $\times$ & $\times$ & $\checkmark$ & $\checkmark$ & \\
$\mathrm{Pb}$ & $\times$ & $\times$ & $\times$ & $\times$ & $\times$ & $\times$ & $\checkmark$ & $\times$ \\
\hline
\end{tabular}

$\checkmark$ : Present; $\times$ : Absent

Table 2: Mean elemental contents in the shoot-tops of Kankong and sweet potato and, ripe bael fruits based on ICP-MS.

\begin{tabular}{|c|c|c|c|c|c|c|c|c|}
\hline \multirow{2}{*}{$\begin{array}{l}\text { Element } \\
(\mathrm{mg} / \mathrm{kg})\end{array}$} & \multicolumn{5}{|c|}{ Bael Accession } & \multicolumn{2}{|c|}{ Kankong } & \multirow[b]{2}{*}{ Sweet potato } \\
\hline & BB & MA & PA & PS & $\mathbf{R A}$ & Market & $\begin{array}{c}\text { Municipal } \\
\text { drain }\end{array}$ & \\
\hline K & $9.43 \times 10^{3} \mathrm{c}$ & $15.70 \times 10^{3} \mathrm{~b}$ & $8.41 \times 10^{3} \mathrm{c}$ & $13.66 \times 10^{3} \mathrm{~b}$ & $12.33 \times 10^{3} \mathrm{~b}$ & $26.08 \times 10^{3} \mathrm{a}$ & $23.60 \times 10^{3} \mathrm{a}$ & $22.62 \times 10^{3} \mathrm{a}$ \\
\hline $\mathrm{Ca}$ & $2.28 \times 10^{3} \mathrm{c}$ & $1.99 \times 10^{3} \mathrm{c}$ & $2.18 \times 10^{3} \mathrm{c}$ & $1.05 \times 10^{3} \mathrm{c}$ & $1.11 \times 10^{3} \mathrm{c}$ & $10.63 \times 10^{3} \mathrm{a}$ & $5.54 \times 10^{3} \mathrm{~b}$ & $4.90 \times 10^{3} \mathrm{~b}$ \\
\hline $\mathrm{Fe}$ & $4.48 \mathrm{f}$ & $1.99 \times 10^{1} \mathrm{e}$ & $4.43 \mathrm{f}$ & $3.54 \times 10^{1} \mathrm{~d}$ & $4.06 \times 10^{1} \mathrm{~d}$ & $3.61 \times 10^{2} \mathrm{~b}$ & $1.34 \times 10^{3} \mathrm{a}$ & $1.03 \times 10^{2} \mathrm{c}$ \\
\hline $\mathrm{Mn}$ & $1.98 \mathrm{c}$ & $2.05 \mathrm{c}$ & $2.11 \mathrm{c}$ & $1.64 \mathrm{c}$ & $2.46 \mathrm{c}$ & $9.10 \times 10^{1} \mathrm{~b}$ & $1.07 \times 10^{2} \mathrm{a}$ & $3.25 \times 10^{1} \mathrm{~b}$ \\
\hline $\mathrm{Zn}$ & $6.69 \mathrm{c}$ & $1.08 \times 10^{1} \mathrm{c}$ & $3.28 \mathrm{c}$ & $1.26 \times 10^{1} \mathrm{c}$ & $0.00 \mathrm{~d}$ & $9.24 \times 10^{1} \mathrm{a}$ & $3.00 \times 10^{1} \mathrm{~b}$ & $8.39 c$ \\
\hline $\mathrm{Cu}$ & $2.96 \mathrm{c}$ & $4.97 \mathrm{c}$ & $1.51 \mathrm{c}$ & $1.73 \times 10^{1} \mathrm{a}$ & $1.43 \times 10^{1} \mathrm{a}$ & $9.78 b$ & $6.46 b$ & $8.54 b$ \\
\hline $\mathrm{Ni}$ & $2.17 b$ & $2.50 \mathrm{~b}$ & $6.56 \times 10^{-1} \mathrm{c}$ & $5.50 \mathrm{a}$ & $3.12 b$ & $7.36 \times 10^{-1} \mathrm{c}$ & $1.54 \mathrm{c}$ & $6.85 \times 10^{-1} \mathrm{c}$ \\
\hline Co & $9.49 \times 10^{-4} \mathrm{c}$ & $1.00 \times 10^{-3} \mathrm{c}$ & $0.00 \mathrm{~d}$ & $2.84 \times 10^{-2} \mathrm{~b}$ & $2.35 \times 10^{-2} \mathrm{~b}$ & $6.66 \times 10^{-1} \mathrm{a}$ & $8.89 \times 10^{-1} \mathrm{a}$ & $6.38 \times 10^{-2} \mathrm{~b}$ \\
\hline $\mathrm{Hg}$ & $1.56 \times 10^{-3} \mathrm{c}$ & $8.18 \times 10^{-4} \mathrm{~d}$ & $5.22 \times 10^{-4} \mathrm{~d}$ & $2.19 \times 10^{-4} \mathrm{~d}$ & $1.15 \times 10^{-3} \mathrm{c}$ & $2.92 \times 10^{-2} \mathrm{~b}$ & $5.42 \times 10^{-2} \mathrm{a}$ & $3.44 \times 10^{-2} \mathrm{~b}$ \\
\hline $\mathrm{Cd}$ & $0.00 \mathrm{c}$ & $0.00 \mathrm{c}$ & $0.00 \mathrm{c}$ & $0.00 \mathrm{c}$ & $0.00 \mathrm{c}$ & $2.86 \times 10^{-2} \mathrm{~b}$ & $6.79 \times 10^{-2} \mathrm{a}$ & $1.63 \times 10^{-2} \mathrm{~b}$ \\
\hline As & $0.00 \mathrm{c}$ & $0.00 \mathrm{c}$ & $0.00 \mathrm{c}$ & $0.00 \mathrm{c}$ & $0.00 \mathrm{c}$ & $4.98 \times 10^{1} \mathrm{a}$ & $2.79 \times 10^{1} \mathrm{~b}$ & $0.00 \mathrm{c}$ \\
\hline $\mathrm{Cr}$ & $1.61 \times 10^{-1} \mathrm{c}$ & $0.00 \mathrm{~d}$ & $1.71 \times 10^{-1} \mathrm{~b}$ & $2.10 \times 10^{-1} \mathrm{c}$ & $0.00 \mathrm{~d}$ & $8.36 \times 10^{-1} \mathrm{a}$ & $2.44 \times 10^{-1} \mathrm{~b}$ & $0.00 \mathrm{~d}$ \\
\hline $\mathrm{Pb}$ & $0.00 \mathrm{c}$ & $8.39 \times 10^{-2} b$ & $0.00 \mathrm{c}$ & $0.00 \mathrm{c}$ & $0.00 \mathrm{c}$ & $0.00 \mathrm{c}$ & $4.08 \times 10^{-1} \mathrm{a}$ & $0.00 \mathrm{c}$ \\
\hline
\end{tabular}

Means denoted by same letters within columns are not significantly different at $\mathrm{P}<0.05$

\section{ICP-MS based assessment of the elemental contents}

\section{Macroelements}

The significantly mean highest content of $\mathrm{K}$ was found in Kankong, and SP and compared to that of bael. The significantly mean highest contents of $\mathrm{Ca}$ were found in KMa samples $\left(10.63 \times 10^{3} \mathrm{mg} / \mathrm{kg}\right)$ compared to the other samples assessed. (Table 2, $\mathrm{P}<0.05$ ).

\section{Microelements}

The significantly highest Fe content was detected in KMa samples $\left(10.63 \times 10^{3} \mathrm{mg} / \mathrm{kg}\right)$ followed by $\mathrm{KMu}$ and SP. The $\mathrm{Fe}$ content was significantly lowest in bael accessions. The significantly highest $\mathrm{Mn}$ content was detected in $\mathrm{KMu}$ followed the by KMa. In bael, Mn was detected, but there were no significant differences among the five bael accessions. The significantly highest content of $\mathrm{Zn}$ was found in KMa whereas the least concentration was found in $\mathrm{SP}$ and bael. The highest contents of $\mathrm{Cu}$ and $\mathrm{Ni}$ were found in bael accessions PS and RA. The highest concentration of Co was found in KMa and KMu samples (Table 2, $\mathrm{P}<0.05$ ).

\section{Toxic elements}

The toxic elements $\mathrm{Cd}$ and As were not detected in bael accessions whereas $\mathrm{Pb}$ was found in the bael accession MA $\left(8.39 \times 10^{-2} \mathrm{mg} / \mathrm{kg}\right)$. The highest $\mathrm{Pb}$ content was found in $\mathrm{KMu}$ samples and no $\mathrm{Pb}$ was detected in KMa or SP. The significantly higher As and $\mathrm{Cr}$ contents were detected in $\mathrm{KMa}$ and $\mathrm{KMu}$ samples and no As or $\mathrm{Cr}$ was detected in SP. The significantly highest $\mathrm{Cd}$ and $\mathrm{Hg}$ content were detected in $\mathrm{KMu}$ samples $\left(6.79 \times 10^{-2}\right.$ and $5.42 \times 10^{-2} \mathrm{mg} / \mathrm{kg}$ respectively). The least $\mathrm{Hg}$ content was detected in bael accessions (Table 2, $\mathrm{P}<0.05$ ). 


\section{Cluster analysis based on elemental contents}

When the elemental contents of ripe fruit pulp of the five bael accessions and Kankong and SP were subjected to cluster analysis, two clear clusters were obtained for bael fruits and GLVs as expected. However, within bael, PA and $\mathrm{BB}$ accessions were clustered together at $94.77 \%$ exhibiting the same pale yellowish color in the powdered samples of these two accessions. The bael accessions RA and PS were clustered together at $93.20 \%$, and MA got clustered with them at $91.29 \%$. These three samples exhibited a dark brown color. The SP and KMu got clustered at $74.07 \%$ showing lighter green color in the powdered samples whereas KMa clustered most distantly. KMa samples exhibited the darkest of the green colors detected (Figure 2).

\section{Correlations among the elemental contents}

In bael, Ca content was significantly associated with $\mathrm{Fe}$, $\mathrm{Co}, \mathrm{Ni}$, and $\mathrm{Cu}$. The correlations among $\mathrm{Zn}$ and $\mathrm{Cr}, \mathrm{Fe}$ and $\mathrm{Co}$, and $\mathrm{Fe}$ and $\mathrm{Cu}$ were significantly and highly correlated in the PCC range of $66.9 \%$ to $79.5 \%$. All the pairwise PCC correlation coefficients detected for the elemental contents in bael pulp are given in Table 2 .

In Kankong, K content was only significantly correlated with $\mathrm{Ca}, \mathrm{Mn}$ and $\mathrm{Cu}$ ( $\mathrm{PCC}$ of 94.3-94.6\%, $\mathrm{P}<0.05$ ). The $\mathrm{Ca}$ content of Kankong was very highly correlated with $\mathrm{Cr}, \mathrm{Ni}, \mathrm{Cu}$ and $\mathrm{Zn}$. It is interesting to note that $\mathrm{Pb}$ and $\mathrm{Cr}, \mathrm{Fe}, \mathrm{Co}, \mathrm{Ni}, \mathrm{Zn}$, and $\mathrm{Hg}$ contents were very highly correlated $(\mathrm{P}<0.05)$. Similarly, $\mathrm{Pb}$ and $\mathrm{Hg}$ contents were also very highly correlated $(\mathrm{P}<0.05)$ indicating almost the coexistence of these two elements in Kankong. All the pair wise elemental correlations for Kankong are given in Table 3. In SP, $100 \%$ PCC was observed between $\mathrm{K}$ and $\mathrm{Ca}, \mathrm{Cu}$ and $\mathrm{K}, \mathrm{Ca}$ and $\mathrm{Cu}, \mathrm{Mn}$ and $\mathrm{Hg}$. All the pair wise elemental correlations for SP are given in Table 4.

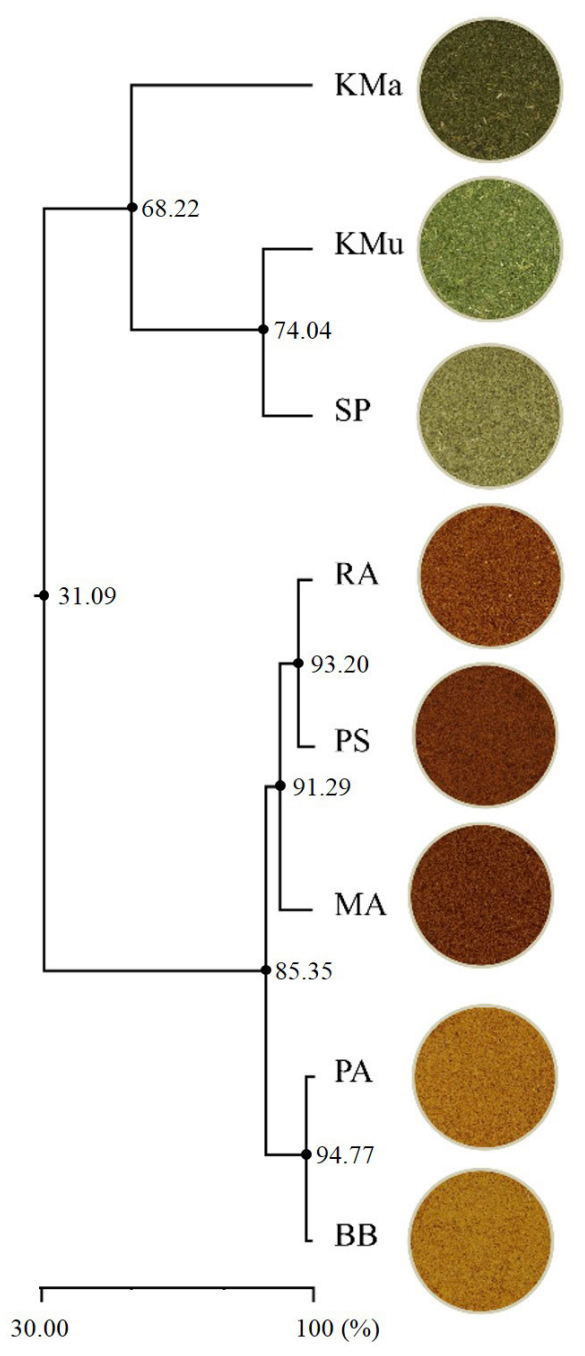

Figure 2: The dendrogram constructed based on the ICP-MS based elemental contents detected for bael, Kankong and SP samples. The $\mathrm{X}$-axis represents the similarity coefficient calculated using Euclidian distance and average linkage algorithms based on the elemental contents. The oven dried powdered samples subjected to ICP-MS were photographed and displayed beside the cluster positions of the respective samples. The Euclidian distances of the clusters are given at each node. 
Table 3: The Pearson Correlation Coefficients (PCC in \%) among the elements in ripe bael fruits.

\begin{tabular}{lllllllllllll}
\hline & \multicolumn{1}{c}{$\mathbf{K}$} & $\mathbf{C a}$ & $\mathbf{C r}$ & $\mathbf{M n}$ & $\mathbf{F e}$ & $\mathbf{C o}$ & $\mathbf{N i}$ & $\mathbf{C u}$ & $\mathbf{Z n}$ & $\mathbf{A s}$ & $\mathbf{C d}$ & $\mathbf{H g}$ \\
\cline { 2 - 12 } $\mathbf{C a}$ & -39.9 & & & & & & & & & & & \\
$\mathbf{C r}$ & 21.5 & -31.1 & & & & & & & & & \\
$\mathbf{M n}$ & -20.2 & 1.3 & -55.0 & & & & & & & & \\
$\mathbf{F e}$ & 54.4 & $-68.0^{*}$ & 54.7 & 15.1 & & & & & & & \\
$\mathbf{C o}$ & 35.5 & $-90.7^{*}$ & 54.3 & -9.2 & $79.5^{*}$ & & & & & & \\
$\mathbf{N i}$ & 58.2 & $-72.9^{*}$ & 57.6 & -38.8 & 57.7 & $82.3^{*}$ & & & & & \\
$\mathbf{C u}$ & 47.3 & $-93.6^{*}$ & 39.5 & -14.3 & $66.9^{*}$ & $93.8^{*}$ & $87.2^{*}$ & & & & & \\
$\mathbf{Z n}$ & 37.4 & 20.4 & $75.2^{*}$ & -44.5 & 36.2 & 2.2 & 21.3 & -10.4 & & & \\
$\mathbf{A s}$ & - & - & - & - & - & - & - & - & - & & & \\
$\mathbf{C d}$ & - & - & - & - & - & - & - & - & - & - & & \\
$\mathbf{H g}$ & -22.8 & 28.5 & -36.3 & 30.7 & -16.3 & -35.8 & -37.0 & -29.9 & -9.9 & - & - & \\
$\mathbf{P b}$ & 34.2 & 3.5 & -16.8 & 29.6 & 4.0 & -26.6 & -11.0 & -18.0 & 14.2 & - & - & 4.0 \\
\hline
\end{tabular}

* indicates significant $\mathrm{PCC}$ at $\mathrm{P}<0.05$

Table 4: The Pearson Correlation Coefficients (PCC in \%) among the elements in Kankong.

\begin{tabular}{|c|c|c|c|c|c|c|c|c|c|c|c|c|}
\hline & $\mathbf{K}$ & $\mathrm{Ca}$ & $\mathrm{Cr}$ & Mn & $\mathrm{Fe}$ & Co & $\mathbf{N i}$ & $\mathrm{Cu}$ & $\mathrm{Zn}$ & As & Cd & $\mathrm{Hg}$ \\
\hline $\mathrm{Ca}$ & $94.3^{*}$ & & & & & & & & & & & \\
\hline $\mathrm{Cr}$ & -89.8 & $-98.7^{*}$ & & & & & & & & & & \\
\hline Mn & $-94.3^{*}$ & -88.3 & 88.1 & & & & & & & & & \\
\hline $\mathrm{Fe}$ & -65.9 & -86.4 & $92.3^{*}$ & 66.9 & & & & & & & & \\
\hline Co & -43.0 & -69.4 & 78.2 & 44.6 & $96.1^{*}$ & & & & & & & \\
\hline $\mathrm{Ni}$ & -85.2 & $-97.4^{*}$ & $96.9^{*}$ & 76.0 & $91.9^{*}$ & 80.5 & & & & & & \\
\hline $\mathrm{Cu}$ & $94.6^{*}$ & $99.3^{*}$ & $-99.2 *$ & $-92.4^{*}$ & -80.6 & -69.6 & $-95.0 *$ & & & & & \\
\hline Zn & 83.8 & $97.0 *$ & $-97.2 *$ & -75.6 & $-93.3 *$ & -82.6 & $-99.9^{*}$ & $94.8^{*}$ & & & & \\
\hline As & -44.0 & -12.7 & - & 35.6 & -38.5 & -62.0 & -5.1 & -12.6 & 8.4 & & & \\
\hline Cd & 1.6 & -31.0 & 37.6 & -9.5 & 67.2 & 83.2 & 51.0 & -26.2 & -53.1 & -82.0 & & \\
\hline Hg & -56.5 & -80.5 & 86.3 & 54.0 & $98.5^{*}$ & $98.3^{*}$ & 89.7 & -79.2 & $-91.2 *$ & -48.2 & 78.6 & \\
\hline $\mathbf{P b}$ & -66.8 & -80.8 & $92.7 *$ & 68.3 & $100 *$ & $95.7^{*}$ & $91.8^{*}$ & -87.3 & $-93.2 *$ & -37.4 & 65.6 & $98.1^{*}$ \\
\hline
\end{tabular}

* indicates significant $\mathrm{PCC}$ at $\mathrm{P}<0.05$

Table 5: The Pearson Correlation Coefficients (PCC in \%) among the elements in sweet potato.

\begin{tabular}{lcccccccccccc}
\hline & $\mathbf{K}$ & $\mathbf{C a}$ & $\mathbf{C r}$ & $\mathbf{M n}$ & $\mathbf{F e}$ & $\mathbf{C o}$ & $\mathbf{N i}$ & $\mathbf{C u}$ & $\mathbf{Z n}$ & $\mathbf{A s}$ & $\mathbf{C d}$ & $\mathbf{H g}$ \\
\hline $\mathbf{C a}$ & $100.0^{*}$ & & & & & & & & & & \\
$\mathbf{C r}$ & - & - & & & & & & & & & \\
$\mathbf{M n}$ & $99.9^{*}$ & $99.8^{*}$ & - & & & & & & & & \\
$\mathbf{F e}$ & -9.1 & -7.5 & - & -13.1 & & & & & & & \\
$\mathbf{C o}$ & -38.8 & -37.4 & - & -42.5 & $95.3^{*}$ & & & & & & \\
$\mathbf{N i}$ & 66.7 & -65.5 & - & -69.6 & 80.3 & $94.6^{*}$ & & & & & \\
$\mathbf{C u}$ & $100.0^{*}$ & $100.0^{*}$ & - & $99.7^{*}$ & -6.0 & -36.0 & -64.4 & & & & \\
$\mathbf{Z n}$ & -88.6 & -89.3 & - & -86.6 & -38.2 & -8.4 & 24.4 & $-90.0^{*}$ & & & \\
$\mathbf{A s}$ & - & - & - & - & - & - & - & - & - & & \\
$\mathbf{C d}$ & $99.1^{*}$ & $99.3^{*}$ & - & $-98.5^{*}$ & 4.4 & -26.1 & -56.1 & $99.5^{*}$ & $-94.0^{*}$ & - & \\
$\mathbf{H g}$ & $99.8^{*}$ & $99.7^{*}$ & - & $100.0^{*}$ & -15.4 & -44.6 & -71.3 & $99.6^{*}$ & -85.4 & - & $98.0^{*}$ \\
$\mathbf{P b}$ & - & - & - & - & - & - & - & - & - & - & - & - \\
\hline
\end{tabular}

* indicates significant $\mathrm{PCC}$ at $\mathrm{P}<0.05$

\section{DISCUSSION}

The assessment of elemental contents in food items is important for making the decisions on the nutrient richness, safety and to provide detailed nutrient profiles of the food items for the consumers. Bael fruits are considered as nutritious and medicinally rich sources and very popular among the people who are concerned about the better health and staying away from the diseases. Kankong is a very popular GLV yet often questioned for its stronger ability to bioaccumulate toxic heavy metals and often can be considered as a natural standard to compare the existence and contents of toxic heavy metals of the other food material. SP shoot tops are an under-utilized GLV yet reported as very highly nutritious vegetable compared with many other vegetable species consumed in the world. Since SP shares the same genus with Kankong, SP shoot-tops can be considered as an alternative to Kankong which are more prone to bioaccumulation of toxic heavy metals. Therefore, it is important to detect the elemental contents of bael fruits to profile its nutrient richness, Kankong to document the presence of toxic heavy metals in samples available in the 
market and harvested from polluted aquatic habitats and SP to showcase that it is an ideal replacement to unsafe Kankong dishes.

There are many methods available to detect elemental contents in biological samples. However, XRF is more convenient, quick and low cost method standing out from the rest. When a calibrated X-ray beam for needed elements hit the finely crushed dried biological samples, the electrons of the internal K, L and M electron shells get excited and removed. The electron vacancies are filled by the electrons in an outer shell with high energy level. This step releases energy with a unique frequency which is captured by the detector and amplified as a spectral signal for a given position of the analysis. Depending on the number of elements present, unique spectral peaks are produced, and the areas of the spectral peaks are proportional to the elemental contents at that point of measurement. So that, this is an ideal method to quickly detect the elements, since there is no complex processing of samples required for XRF. However, XRF is providing a qualitative assessment often used to check the presence of an element and rather than the specific quantity. The XRF analysis is a routine method in India to check the elemental contents of bael (Sarma and Goswami, 2016; Sharma and Chauhan, 2016; Vishwakarma and Dubey, 2011). According to the XRF analysis, the heavy metals $\mathrm{Hg}, \mathrm{Cd}, \mathrm{As}, \mathrm{Cr}$, and $\mathrm{Pb}$ were absent in all the bael accessions and SP. The $\mathrm{Pb}$ was also absent in KMa. The micro nutrient Mn was also absent in SP. All the other elements were positively detected in samples tested (Table 1; Figure 1). Except Mn in SP for all the macro and micro nutrients, ICP-MS analysis also provided the elemental presence as revealed by XRF. However, in the toxic heavy metals, minute amounts were detected for certain elements and some bale accessions in the ICP-MS analysis (Table 2). Therefore, to detect the smaller quantities of toxic elements ICP-MS method must be preferred over XRF analysis.

It is evident from the ICP-MS analysis that ripe bael fruits are safe to eat because of the absence of toxic heavy metals $\mathrm{Cd}, \mathrm{As}$ and $\mathrm{Pb}$ in them (Table 2). However, we detected a trace amount of $\mathrm{Pb}$ in the bael accession MA. This accession is located at a site with higher exposure to vehicles and industrial activities. Bael fruit pulp contained appreciable amounts of macro and micro elements tested, highlighting its superior nutritional value. Although, no As detected in bael fruit pulp in our study, Bhat et al., (2010) has reported traces of As in bark tissues and Tiagi and Aery, (1981) reported the absence of $\mathrm{Cd}$ and presence of $\mathrm{Pb}$ in bael grown in Zawar, Rajasthan, India implying that these elemental contents are region or soil specific. Santra et al., (2008) has conducted an elemental analysis on bael as a nutritious fodder to wild elephants in India. In Kankong, $\mathrm{KMa}$ samples contained the toxic heavy metals $\mathrm{Hg}, \mathrm{Cd}$, $\mathrm{As}$, and $\mathrm{Cr}$ in significantly higher amounts implying that the market samples are coming from sites that are polluted with toxic heavy metals. The KMu sample contained all the toxic heavy metals assessed and more importantly it contained a high amount of $\mathrm{Pb}$. These data demonstrated that Kankong available in Sri Lanka are contaminated with toxic heavy metals and unsafe for consumption and these data are comparable to the reported studies (Gothberg et al., 2004). The toxic heavy metals like $\mathrm{Hg}, \mathrm{As}, \mathrm{Cd}$, and $\mathrm{Pb}$ are reported to be causing severe ailments such as kidney diseases, cancers, and neurological dysfunctions. However, Kankong samples assessed contained significantly higher amounts of macro and microelements implying that if they are grown in non-polluted safe habitats, they are suitable for human consumption as a nutritious vegetable. SP shoot tops did not contain $\mathrm{As}$ and $\mathrm{Pb}$ (Table 1) indicating that it is a substitute for Kankong. SP is reported to be richer in bioactive phytochemicals (Sun et al., 2014) than Kankong or any other green leafy vegetable (Li et al., 2017; Karna et al., 2011; Johnson and Pace, 2016).

The correlation analysis conducted for pair-wise elemental contents separately for different species revealed that group wise elemental absorption exists but the mechanisms are species specific. For example, in bael, $\mathrm{Ca}$ content is correlated separately with $\mathrm{Fe}, \mathrm{Co}, \mathrm{Ni}$, and $\mathrm{Cu}$. The $\mathrm{Fe}$ content is correlated with $\mathrm{Co}$ and $\mathrm{Cu}$ (Table 3). These correlations imply that the elements might be absorbed and deposited in bael pulp as groups. Such concurrent heavy metals absorptions are reported for vegetables and GLVs (Mattina et al., 2003).

Similar correlations were not observed in Kankong but more specifically toxic heavy metals $\mathrm{Pb}$ and $\mathrm{Hg}$ are correlated (Table 4) implying that they get absorbed as groups and accumulated in above ground shoots. Also, it is possible to speculate that the growing sites of Kankong are contaminated with toxic heavy metals elements that are coexisting or coming from common sources, however, further research is needed to verify these hypotheses. The higher correlation of heavy metal contents in Kankong also suggest that it would be an ideal candidate plant to phytoremediate the soils contaminate with multiple heavy metals as purifying element by using chemical methods would be an expensive and time consuming approach.

In SP, $\mathrm{K}$ and $\mathrm{Ca}$ contents are correlated with each other (Table 5). It is logical to think that SP absorbs elements individually compared to Kankong which prefers to absorb elements as groups. The data of the present study on the elemental contents in plant tissues in a species-specific manner demands further research to dissect the underlying the molecular genetics and physiological mechanisms for in-depth understanding to broaden the field of plant nutrition.

\section{CONCLUSION}

The XRF and ICP-MS analysis based detection of the elemental contents of the pulp of ripe bael fruits and green leafy vegetables Kankong and sweet potato revealed that bael and sweet potato are safe for human consumption because of the absence of $\mathrm{As}$ and $\mathrm{Pb}$ and the presence of macro an micronutrient elements. However, Kankong samples are unsafe to eat as they contain toxic heavy metals such as $\mathrm{As}, \mathrm{Hg}, \mathrm{Cd}$, and $\mathrm{Pb}$. The present study also demonstrates the potential of employing XRF analysis as a quick and low-cost method to detect the elemental profiles of food samples for safety analysis and nutrient profiling. 


\section{ACKNOWLEDGMENTS}

National Science Foundation, Sri Lanka Research Grant (RG/2015/BT/05); Departments of Physics and Geology, Faculty of Science, University of Peradeniya for the provision of XRF and ICP-MS facilities.

\section{REFERENCES}

Bhat, R., Kiran, K., Arun, A.B. and Karim, A.A. (2010). Determination of mineral composition and heavy metal content of some nutraceutically valued plant products. Food Analytical Methods 3: 181-187.

Diyabalanage, S., Fonseka, S., Dasanayake, D.M.S.N.B. and Chandrajith, R. (2017). Environmental exposures of trace elements assessed using keratinized matrices from patients with chronic kidney diseases of uncertain etiology (CKDu) in Sri Lanka. Journal of Trace Elements in Medicine and Biology 39: 62-70.

Göthberg, A., Greger, M., Bengtsson, B.E. (2002). Accumulation of heavy metals in water spinach (Ipomoea aquatica) cultivated in the Bangkok Region, Thailand. Environmental Toxicology Chemistry 21(9): 1934-1939.

Göthberg, A., Gregerb, M., Holma, K. and Bengtssona, B. (2004). Influence of nutrient levels on uptake and effects of mercury, cadmium, and lead in water spinach. Journal of Environmental Quality 33(4): 1247-1255.

Islam, S. (2014). Nutritional and medicinal qualities of sweetpotato tops and leaves. Cooperative Extension Service, University of Arkansas, USA. Available from https://www.uaex.edu/publications/PDF/FSA-6135.pdf (Aug. 15, 2018).

Johnson, M. and Pace, R.D. (2010). Sweet potato leaves: properties and synergistic interactions that promote health and prevent disease. Nutrition Reviews 68(10): 604-615.

Karmakar, K., Muslim, T. and Rahman, M.A. (2013). Chemical composition of some leafy vegetables of Bangladesh. Dhaka University Journal of Science 61(2): 199-201.

Karna, P., Gundala, S.R., Gupta, M.V., Shamsi, S.A., Pace, R.D., Yates, C., Narayan, S. and Aneja, R. (2011). Polyphenol-rich sweet potato greens extract inhibits proliferation and induces apoptosis in prostate cancer cells in vitro and in vivo. Carcinogenesis 32(12): 1872 1880 .

Kaur, A. and Kalia, M. (2017). Physico chemical analysis of bael (Aegle Marmelos) fruit pulp, seed and pericarp. Chemical Science Review and Letters 6(22): 12131218.

Kavitha, V. and Ramadas, V.S. (2013). Nutritional composition of raw fresh and shade dried form of spinach leaf (Spinach oleracea). JPR BioMedRx 1: 767-770.

Li, M., Jang, G.Y., Lee, S.H., Kim, M.Y., Hwang, S.G., Sin, H.M., Kim, H.S., Lee, J. and Jeong, H.S. (2017). Comparison of functional components in various sweet potato leaves and stalks. Food Science and Biotechnology 26(1): 97-103.

Liu, W.H., Zhao, J.Z., Ouyang, Z.Y., Söderlund, L. and Liu, G.H. (2005). Impacts of sewage irrigation on heavy metal distribution and contamination in Beijing, China. Environment International 31(6): 805-812.

Marcussen, H., Joergensen, K., Holm, P.E., Brocca, D., Simmons, R.W. and Dalsgaard, A. (2008). Element contents and food safety of water spinach (Ipomoea aquatica Forssk.) cultivated with wastewater in Hanoi, Vietnam. Environmental Monitoring and Assessment 139(1-3): 77-91.

Mattina, M.I., Lannucci-Berger, W., Musante, C. and White, J.C. (2003). Concurrent plant uptake of heavy metals and persistent organic pollutants from soil. Environmental Pollution 124(3): 375-378.

Menelaou, E., Kachatryan, A., Losso, J.N., Cavalier, M. and La Bonte, D. (2006). Lutein content in sweet potato leaves. Hort Science 41(5):1269-1271.

Mishra, B., Kushwaha, R. and Pandey, F.K. (2012). Determination and comparative study of mineral elements and nutritive value of some common fruit plants. International Journal of Pure and Applied Sciences and Technology 2(2): 64-72.

Mulokozi, G., Mugyabuso, J. and Modaha, F. (2007). Potential of cassava and sweet potato leaves to contribute to the vitamin A requirements. In Proceedings of the $13^{\text {th }}$ ISTRC Symposium pp 755-762.

Nagai, M., Tani, M., Kishimoto, Y., Iizuka, M., Saita, E., Toyozaki, M., Kamiya, T., Ikeguchi, M. and Kondo, K. (2011). Sweet potato (Ipomoea batatas L.) leaves suppressed oxidation of low density lipoprotein (LDL) in vitro and in human subjects. Journal of Clinical Biochemistry and Nutrition 48(3): 203-208.

Nielson, K.K., Mahoney, A.W., Williams, L.S. and Rogers, V.C. (1991). X-ray fluorescence measurements of $\mathrm{Mg}$, $\mathrm{P}, \mathrm{S}, \mathrm{Cl}, \mathrm{K}, \mathrm{Ca}, \mathrm{Mn}, \mathrm{Fe}, \mathrm{Cu}$, and $\mathrm{Zn}$ in fruits, vegetables, and grain products. Journal of Food Composition and Analysis 4(1): 39-51.

Santra, A.K., Pan, S., Samanta, A.K., Das, S. and Halder, S. (2008). Nutritional status of forage plants and their use by wild elephants in South West Bengal, India. Tropical Ecology 49(2): 251.

Sarma, B. and Goswami, B.C. (2016). Qualitative elemental analysis of some selected antidiabetic medicinal plants of Assam using X-ray Fluorescence (XRF) technique. Asian Journal of Plant Science and Research 6(3): 7179.

Sharma, K. and Chauhan, E.S. (2016). Nutritional and phytochemical evaluation of fruit pulp powder of Aegle marmelos (Bael). Journal of Chemical and Pharmaceutical Sciences 10: 809-814.

Singh, U., Kocher, A. and Boora, R. (2012). Proximate composition, available carbohydrates, dietary fibres and anti-Nutritional factors in bael (Aegle marmelos L.) leaf, pulp and seed powder. International Journal of Scientific and Research Publications 2(4): 1-4.

Sun, H., Mu, T., Xi, L., Zhang, M. and Chen, J. (2014). Sweet potato (Ipomoea batatas L.) leaves as nutritional and functional foods. Food Chemistry 156: 380-389.

Tiagi, Y.D. and Aery, N.C. (1981). Biogeochemical studies in Zinc deposit areas of Zawar mines, Rajasthan, India. Proceedings of the Indian National Science Academy B 47(6): 867-887.

Vishwakarma, K.L. and Dubey, V. (2011). Nutritional 
analysis of indigenous wild edible herbs used in Eastern Chhattisgarh, India. Emirates Journal of Food and Agriculture 23(6): 554-560.

Wijewardana, R.M.N.A., Nawarathne, S.B., Wickramasinghe, I., Gunawardane, C.R., Wasala, W.M.C.B. and Thilakarathne, B.M.K.S. (2016). Retention of physicochemical and antioxidant properties of dehydrated bael (Aegle marmelos) and palmyra (Borassus flabellifer) fruit powders. Procedia Food Science 6: 170-175. 